\title{
Thrombectomy for acute large vessel occlusion in posterior and anterior circulation: a single institutional retrospective observational study
}

\author{
Tomoyoshi Kuribara $^{1} \cdot$ Satoshi lihoshi ${ }^{1}$ (D) Eisuke Tsukagoshi ${ }^{1} \cdot$ Akio Teranishi $^{1}$ - Yu Kinoshita ${ }^{1}$. Shin Sugasawa ${ }^{1}$. \\ Shinya Kohyama ${ }^{1} \cdot$ Shinichi Takahashi $^{2} \cdot$ Hiroki Kurita $^{3}$
}

Received: 8 June 2021 / Accepted: 28 August 2021 / Published online: 3 September 2021

(c) The Author(s) 2021

\begin{abstract}
Purpose Thrombectomy has been the gold standard therapy for anterior circulation occlusion; however, studies regarding thrombectomy in posterior circulation are lacking. In this study, we compared the efficiency of thrombectomy for acute large vessel occlusion between the posterior and anterior circulation at a single institution.

Methods We retrospectively analyzed consecutive patients who underwent thrombectomy for acute large vessel occlusion at our institution between August 2014 and April 2021. Differences in the clinical background, time course, and treatment technique and outcomes were evaluated between anterior and posterior circulation occlusions.

Results Overall, 353 patients (225 men and 128 women) were included: 314 patients had anterior circulation occlusion and 39 patients had posterior circulation occlusion. Between the patients with anterior and posterior circulation occlusions, the National Institutes of Health Stroke Scale (NIHSS) score (16 [12-21] vs. 29 [19-34], respectively, $p<0.001$ ), doorto-puncture time (65 [45-99] vs. 99 [51-121] min, respectively, $p=0.018$ ), and mortality (22 [7\%] vs. 8 [20.5\%] patients, respectively, $p=0.010$ ) were significantly different; however, favorable outcome was not significantly different.

Conclusion Higher NIHSS score, delayed treatment, and higher mortality were observed in posterior circulation occlusion than in anterior circulation occlusion; successful reperfusion and favorable outcomes were similar between them. Similar favorable outcomes and reperfusion ratio to the anterior circulation might be achieved also in the posterior circulation; however, delayed treatment and the optimal first-pass strategy might need further improvement.
\end{abstract}

Keywords Thrombectomy $\cdot$ Acute large vessel occlusion $\cdot$ Posterior circulation $\cdot$ Anterior circulation

\section{Introduction}

The effectiveness of thrombectomy using conventional devices for acute large vessel occlusion was lacking evidence for a long time [1-3]. However, this procedure has

Satoshi Iihoshi

si95461@5931.saitama-med.ac.jp

1 Department of Endovascular Neurosurgery, Saitama Medical University International Medical Center, 1397-1 Yamane, Hidaka, Saitama 350-1298, Japan

2 Department of Neurology and Cerebrovascular Medicine, Saitama Medical University International Medical Center, Hidaka, Saitama, Japan

3 Department of Cerebrovascular Surgery, Saitama Medical University International Medical Center, Hidaka, Saitama, Japan been accepted as the gold standard therapy based on evidence from five randomized controlled trials in which a stent retriever was used as the main device [4-8]. Additionally, a meta-analysis of these studies and two subsequent randomized controlled trials also confirmed the effectiveness of thrombectomy [9-11]. Subsequently, studies shifted their focus toward expanding the indications of eligible patients and improving the revascularization rate. The aforementioned studies reported the effectiveness of the procedure within $6 \mathrm{~h}$ from onset; however, two subsequent randomized controlled trials reported its effectiveness even after $6 \mathrm{~h}$ from onset in cases of mismatch between the clinical and imaging findings $[12,13]$. Furthermore, the contact aspiration technique using large-bore catheters has been reported to be as effective as the stent retriever [14]; their combination is expected to improve the revascularization rate [15-18]. However, these studies focused on acute large vessel 
occlusion in the anterior circulation, and similar evidence in the posterior circulation remains lacking.

Posterior circulation occlusion, especially basilar artery (BA) occlusion, constitutes approximately $5 \%$ of large vessel occlusions $[19,20]$. It is reported to result in a higher National Institutes of Health Stroke Scale (NIHSS) score, higher mortality, and lower rate of favorable outcomes in comparison with anterior circulation occlusion [21-25]. Despite the relatively high successful reperfusion rate, worse outcomes have been reported in prospective registry studies [26, 27]. A recent randomized controlled trial has reported no superiority of thrombectomy over the standard medical treatment within $8 \mathrm{~h}$ from onset [28]. Therefore, the optimal treatment strategy remains controversial. In contrast, a higher posterior circulation Alberta Stroke Program Early Computed Tomography Score (pc-ASPECTS), collateral status, shorter onset-to-reperfusion time, lower NIHSS score, higher Glasgow Coma Scale sum score, and lower baseline glycemic level have been reported to be associated with better outcomes [24, 29-31]. Therefore, better understanding of this disease might result in better outcomes. In this study, we evaluated and compared the characteristics of posterior circulation occlusion with those of anterior circulation occlusion at a single institution.

\section{Materials and methods}

\section{Patients}

This study protocol was approved by the ethics committee of our institution, and all patients provided informed consent with an opt-out policy. Between August 2014 and April 2021, consecutive patients who underwent thrombectomy for acute large vessel occlusion were enrolled in this study. In patients who underwent thrombectomy more than once during the study period at our institution, only the first procedure was evaluated. At our institution, the indications for thrombectomy included (1) acute large vessel occlusion (internal carotid artery [ICA]; the first segment of the middle cerebral artery [MCA], M1; the second segment of the MCA, M2; BA; vertebral artery [VA]) within $6 \mathrm{~h}$ from onset; (2) NIHSS score [32] $\geq 6$; (3) DWI-ASPECTS [33] $\geq 6$ in ICA and M1 occlusion [9]; (4) mismatch area $\geq 1$ in DWI-ASPECTS between hyperintensity on diffusion-weighted imaging (DWI) and estimated perfusion area of the occluded vessel on magnetic resonance imaging (MRI) and magnetic resonance angiography (MRA) in M2 occlusion; (5) no pc-ASPECTS [34] based on DWI limit; and (6) no age limit. Patients with pre-onset modified Rankin Scale (mRS) [35] score $\geq 3$ or early ischemic core $\leq 5$ in DWI-ASPECTS were excluded. Additionally, recombinant tissue-type plasminogen activator (rt-PA) was intravenously administered to patients who had no contraindications within $4.5 \mathrm{~h}$ from onset. The MRI first policy is used for patients with suspected stroke using the 1.5-T or 3.0-T MRI system at our institution. Despite varied evaluation equipment, DWI, MRA, fluid-attenuated inversion recovery imaging, and $\mathrm{T} 2$ - or $\mathrm{T} 2{ }^{*}$-weighted imaging have been routinely performed. In cases of inter-hospital transfer, we used the former hospital's MRI and MRA evaluation as references. In MRA evaluation, the perfusion area of occluded vessels was assumed based on the location of these vessels, and no specific perfusion image evaluation was performed.

For patients with contraindications to MRI, non-contrast computed tomography (CT) or CT angiography was performed. Differences in clinical background, time course, and treatment outcomes were retrospectively evaluated between anterior and posterior circulation occlusions.

\section{Thrombectomy}

The treatment strategy depended on several factors, such as the neuroendovascular surgeons, periods (differences in treatment devices and evidence at the time of treatment), location of lesion, and access routes. However, generally, all procedures were performed using biplane digital subtraction angiography equipment under sedation. For patients who needed endotracheal intubation due to impaired consciousness, general anesthesia was administered. The transfemoral approach was used, and the guiding catheter was navigated to the proximal portion of the occluded vessel along with an inner catheter and guidewire. Subsequently, the microcatheter was navigated to the distal portion of the occluded vessel with a microguidewire, and first-pass devices (stent alone, aspiration catheter alone, combined stent retriever with aspiration catheter, or other devices: percutaneous transluminal angioplasty [PTA] balloon, microguidewire and microcatheter, balloon guiding catheter [for suction], and stent) were used. The devices were removed during manual aspiration through the guiding catheter. This process was repeated until successful reperfusion was achieved. Additionally, angioplasty, stent placement, and medical therapies (other than rt-PA) were performed for residual spastic, atherosclerotic, or dissociative lesions. The degree of reperfusion was evaluated using the Thrombolysis in Cerebral Ischemia (TICI) scale [36]; TICI grade $\geq 2 \mathrm{~B}$ was defined as successful reperfusion. In cases with difficulties in reperfusion, we terminated the procedure based on the onset time, perfusion area of the occluded vessel, and benefits of reperfusion after four passes. Treatment outcome was evaluated using $\mathrm{mRS}$ at discharge, and $\mathrm{mRS} \leq 2$ was defined as a favorable outcome. 


\section{Statistical analysis}

Data are expressed as median (interquartile range [IQR]). The Mann-Whitney $U$ test, Fisher's exact test, and Pearson's chi-square test were used to compare the anterior and posterior circulation occlusions. Statistical analyses were performed using SPSS v26 (IBM Corp., Armonk, NY, USA), and $p$ values $<0.05$ indicated statistical significance. About the background characteristics, such as age, sex, comorbidity, history of smoking, inter-hospital transfer, drip-and-ship, in-hospital onset, NIHSS score, left-sided lesion, location of lesion, DWI-ASPECTS, pc-ASPECTS based on DWI, disease subtype, and tandem lesions, were evaluated. Regarding the treatment and outcome, intravenous rt-PA, first-pass devices (the devices used in the first passes), PTA, stent placement, medical therapy (other than rt-PA), time course, TICI 2B-3 reperfusion, TICI 3 reperfusion, first-pass TICI 2B-3 reperfusion, symptomatic complications, hospitalization period, $\mathrm{mRS}$ at discharge, favorable outcomes, and mortality were evaluated.

\section{Results}

\section{Background characteristics}

A total of 353 patients ( 225 men and 128 women) were included in the study. The median age was $76(69-82)$ years (range, 32-96). A total of 314 patients had anterior circulation occlusion, and 39 patients had posterior circulation occlusion. The background data of patients with anterior and posterior circulation occlusions are summarized in Table 1. The locations of the lesions included the ICA $(n=120)$; M1 $(n=185) ; \mathrm{M} 2(n=43) ; \mathrm{BA}(n=37) ; \mathrm{VA}(n=6)$; tandem lesions $(n=37)$; and bilateral lesions $(n=1)$. Between the patients with anterior and posterior circulation occlusions, the NIHSS score (16 [12-21] vs. 29 [19-34], respectively, $p<0.001)$ and intracranial stenotic occlusions (26 [8.3\%] vs. 9 [23.1\%] patients, respectively, $p=0.008$ ) were significantly different; however, other characteristics (age, sex, comorbidities, history of smoking, inter-hospital transfer, drip-and-ship, in-hospital onset, left-sided lesion, preprocedural MRI evaluation, location of lesion, DWI-ASPECTS, pc-ASPECTS based on DWI, disease subtype, tandem lesion, and extracranial stenotic occlusion) demonstrated no significant differences.

\section{Treatment, time course, and outcome}

The treatment, time course, and outcomes are summarized in Table 2. Intravenous rt-PA was administered to 180 (51.0\%) patients. The first-pass devices included the stent retriever in $101(28.6 \%)$ patients, aspiration catheter in 123 (34.8\%) patients, combined approach in $103(29.2 \%)$ patients, and other devices in $26(7.4 \%)$ patients (PTA [ $n=14]$, microguidewire and microcatheter $[n=2]$, suction through a balloon guiding catheter $[n=4]$, stent placement $[n=1]$, and inaccessible $[n=5])$. PTA was performed in $46(13.0 \%)$ patients, stent placement in 19 (5.4\%) patients, and medical therapy other than rt-PA in 35 (9.9\%) patients. Stent placement was performed for both intracranial and extracranial steno-occlusive lesions (cervical ICA [ $n=15], \mathrm{M} 1[n=2]$, BA $[n=1]$, and extracranial VA $[n=1])$. The details of the stents and location were as follows: Carotid Wallstent (Boston Scientific, Natick, MA, USA) (cervical ICA $[n=12]$ ), Integrity bare metal stent (Medtronic, Minneapolis, MN, USA) (M1 $[n=1]$, BA $[n=1]$, and extracranial VA $[n=1])$, Enterprise 2 VRD (Codman Neurovascular, Johnson \& Johnson, Miami, FL, USA) (cervical ICA [ $n=2]$ ), the Wingspan Stent System (Stryker, Kalamazoo, MI, USA) (M1 $[n=1])$, and CASPER stent (Microvention, Terumo, Tustin, CA, USA) (cervical ICA $[n=1])$. Between the patients with anterior and posterior circulation occlusions, the door-to-picture time (17 [12-24] vs. 24 [16-36] min, respectively, $p=0.005$ ), doorto-needle time (72 [61-85] vs. 93 [83-123] min, respectively, $p<0.001$ ), door-to-puncture time (65 [45-99] vs. 99 [51-121] min, respectively, $p=0.018$ ), door-to-reperfusion time (125 [90-156] vs. 163 [121-203] min, respectively, $p=0.004$ ), the number of passes in the cases that were not achieved successful reperfusion in the first pass (3[2-4] vs. $2[2,3]$, respectively, $p=0.036)$, and mortality (22 [7\%] vs. 8 [20.5\%] patients, respectively, $p=0.010$ ) were significantly different. However, other characteristics, such as intravenous rt-PA, first-pass devices, PTA, stent placement, medical therapy other than rt-PA, onset-to-door time, puncture-to-reperfusion time, onset-to-reperfusion time, TICI 3 reperfusion, first-pass TICI 2B-3 reperfusion, symptomatic complications, and $\mathrm{mRS}$ at discharge, demonstrated no significant differences between them. Particularly, TICI 2B-3 reperfusion (257 [81.8\%] vs. 30 [76.9\%] patients, respectively, $p=0.457$ ) and favorable outcome (106 [33.8\%] vs. 12 [30.8\%] patients, respectively, $p=0.709$ ) were not significantly different between the patients. The details of $\mathrm{mRS}$ at discharge in all patients and in those with anterior and posterior circulation occlusions are summarized in Fig. 1.

In addition, subgroup analysis according to the firstpass device was performed, and puncture-to-reperfusion time, rate of TICI 2B-3 reperfusion, TICI 3 reperfusion, first-pass TICI 2B-3 reperfusion, symptomatic complications, favorable outcome, and mortality due to first-pass devices were evaluated (Table 3 ). In those with anterior circulation occlusion, a longer puncture-to-reperfusion time was observed with the combined approach than that with the aspiration catheter alone (53.5 [36.5-77] vs. 41.5 [28-69] $\mathrm{min}$, respectively, $p=0.045$ ); however, there was no significant difference between other devices and 
Table 1 Background data of patients with anterior and posterior circulation occlusion

\begin{tabular}{|c|c|c|c|c|}
\hline Characteristics & Total & $\begin{array}{l}\text { Anterior circula- } \\
\text { tion occlusion }\end{array}$ & $\begin{array}{l}\text { Posterior circula- } \\
\text { tion occlusion }\end{array}$ & $p$ value \\
\hline Number of patients & 353 & 314 & 39 & \\
\hline Age, median (IQR), y & $76(69-82)$ & $76(69-82)$ & $74(69-79.5)$ & 0.310 \\
\hline Sex, male $(\%)$ & $225(63.7)$ & $197(62.7)$ & $28(71.8)$ & 0.267 \\
\hline \multicolumn{5}{|l|}{ Coexisting disease } \\
\hline Hypertension (\%) & $209(59.2)$ & $186(59.2)$ & $23(59.0)$ & 0.975 \\
\hline Diabetes mellitus (\%) & $80(22.7)$ & $71(22.6)$ & $9(23.1)$ & 0.948 \\
\hline Hyperlipidemia (\%) & $98(27.8)$ & $90(28.7)$ & $8(20.5)$ & 0.284 \\
\hline Atrial fibrillation (\%) & $200(56.7)$ & $181(57.6)$ & $19(48.7)$ & 0.289 \\
\hline Coronary artery disease $(\%)$ & $48(13.6)$ & $39(12.4)$ & $9(23.1)$ & 0.067 \\
\hline Previous smoking (\%) & $120(34.0)$ & $109(34.7)$ & $11(28.2)$ & 0.418 \\
\hline Inter-hospital transfer (\%) & $83(23.5)$ & $70(22.3)$ & $13(33.3)$ & 0.125 \\
\hline Drip-and-ship (\%) & $24(6.8)$ & $19(6.1)$ & $5(12.8)$ & 0.165 \\
\hline In-hospital onset (\%) & $25(7.1)$ & $23(7.3)$ & $2(5.1)$ & 1.000 \\
\hline NIHSS score, median (IQR) & $17(12-23)$ & $16(12-21)$ & $29(19-34)$ & $<0.001^{*}$ \\
\hline Left-sided lesion (\%) & $150(42.5)$ & $148(47.1)$ & $2(5.1)$ & \\
\hline \multicolumn{5}{|l|}{ Location of lesion } \\
\hline $\mathrm{ICA}(\%)$ & & $120(38.2)$ & & \\
\hline M1 (\%) & & $185(58.9)$ & & \\
\hline M2 (\%) & & 43 (13.7) & & \\
\hline $\mathrm{BA}(\%)$ & & & 37 (94.9) & \\
\hline VA $(\%)$ & & & $6(15.4)$ & \\
\hline ASPECTS, median (IQR) & & $8(6-9)$ & & \\
\hline pc-ASPECTS, median (IQR) & & & $7(6-8.5)$ & \\
\hline \multicolumn{5}{|l|}{ Disease subtype } \\
\hline Cardiogenic (\%) & $212(60.1)$ & $193(61.5)$ & 19 (48.7) & 0.125 \\
\hline Atherosclerotic (\%) & $76(21.5)$ & $65(20.7)$ & $11(28.2)$ & 0.282 \\
\hline Others $(\%)$ & $65(18.4)$ & $56(17.8)$ & $9(23.1)$ & 0.426 \\
\hline Tandem lesion & $37(10.5)$ & $33(10.5)$ & $4(10.3)$ & 1.000 \\
\hline Intracranial stenotic lesion (\%) & $35(9.9)$ & $26(8.3)$ & $9(23.1)$ & $0.008 *$ \\
\hline Extracranial stenotic lesion (\%) & $41(11.6)$ & $39(12.4)$ & $2(5.1)$ & 0.286 \\
\hline
\end{tabular}

${ }^{*} p<0.05 . I Q R$ interquartile range, NIHSS Institutes of Health Stroke Scale, ICA internal carotid artery, MI first segment of middle cerebral artery, $M 2$ second segment of middle cerebral artery, $B A$ basilar artery, VA vertebral artery, ASPECTS Alberta Stroke Program Early Computed Tomography Score, $p c$ posterior circulation posterior circulation occlusion. In patients with posterior circulation occlusion, a higher rate of first-pass TICI 2B-3 reperfusion was observed with stent retrievers than that with aspiration catheters (9 [81.8\%] vs. 5 [38.5\%] patients, respectively, $p=0.047$ ); however, there was no significant difference among other devices and anterior circulation occlusion. A higher rate of hemorrhagic complications was observed with the combined approach than with the aspiration catheter $(3[2.7 \%]$ vs. 10 [10.8\%] patients, respectively, $p=0.020$ ) in anterior circulation, while there was no significant difference among other devices and anterior circulation occlusion. In addition, BA stenotic occlusions were seen in 2 (18.2\%), 2 (15.4\%), 3 (30.0\%), and $2(40 \%)$ patients who underwent thrombectomy with stent retriever, aspiration catheter, combined approach, and other devices as first-pass devices for posterior circulation occlusion, respectively.

\section{Discussion}

\section{Differences between anterior and posterior circulation occlusions}

In this study, we evaluated the characteristics of patients with posterior circulation occlusion and compared them with those with anterior circulation occlusion. Higher NIHSS; more intracranial stenotic lesions; longer door-to-picture time, door-to-needle time, door-to-puncture time, and doorto-reperfusion time; fewer passes; and higher mortality were 
Table 2 Treatment, time course, and outcomes in patients with anterior and posterior circulation occlusion

\begin{tabular}{|c|c|c|c|c|}
\hline Characteristics & Total & $\begin{array}{l}\text { Anterior circulation } \\
\text { occlusion }\end{array}$ & $\begin{array}{l}\text { Posterior circulation } \\
\text { occlusion }\end{array}$ & $p$ value \\
\hline Intravenous rt-PA (\%) & $180(51.0)$ & $162(51.6)$ & $18(46.2)$ & 0.522 \\
\hline \multicolumn{5}{|l|}{ First-pass devices } \\
\hline Stent retriever $(\%)$ & $101(28.6)$ & $90(28.7)$ & $11(28.2)$ & 0.952 \\
\hline Aspiration catheter $(\%)$ & $123(34.8)$ & $110(35.0)$ & $13(33.3)$ & 0.834 \\
\hline Combined approach (\%) & $103(29.2)$ & $93(29.6)$ & $10(25.6)$ & 0.606 \\
\hline Other devices $(\%)$ & $26(7.4)$ & $21(6.7)$ & $5(12.8)$ & 0.187 \\
\hline PTA $(\%)$ & $46(13.0)$ & $41(13.1)$ & $5(12.8)$ & 0.967 \\
\hline Stent placement (\%) & $19(5.4)$ & $17(5.4)$ & $2(5.1)$ & 1.000 \\
\hline Medical therapy other than rt-PA (\%) & $35(9.9)$ & 34 10.8) & $1(2.6)$ & 0.152 \\
\hline \multicolumn{5}{|l|}{ Time course } \\
\hline Onset-to-door time, median (IQR), min & $112.5(58.8-240.5)$ & $112(60-241)$ & $117(53-314)$ & 0.888 \\
\hline Door-to-picture time, median (IQR), min & $17(12-25)$ & $17(12-24)$ & $24(16-36)$ & $0.005^{*}$ \\
\hline Door-to-needle time, median (IQR), min & $74(61-89)$ & $72(61-85)$ & $93(83-123)$ & $<0.001 *$ \\
\hline Door-to-puncture time, median (IQR), min & $69(46-102)$ & $65(45-99)$ & $99(51-121)$ & $0.018^{*}$ \\
\hline Picture to puncture time, median (IQR), min & $56.5(36-80.3)$ & $52(35-76.5)$ & $77(60-96)$ & $0.001 *$ \\
\hline Puncture-to-reperfusion time, median (IQR), min & $49(31-74)$ & $48(31-74)$ & $52(37-77)$ & 0.384 \\
\hline Door-to-reperfusion time, median (IQR), min & $127(93-165)$ & $125(90-156)$ & $163(121-203)$ & $0.004 *$ \\
\hline Onset-to-reperfusion time, median (IQR), min & $270(195-376)$ & $267(191-370)$ & $295(231-442)$ & 0.079 \\
\hline TICI 2B-3 reperfusion (\%) & $287(81.3)$ & $257(81.8)$ & $30(76.9)$ & 0.457 \\
\hline TICI 3 reperfusion (\%) & $160(45.3)$ & $141(44.9)$ & $19(48.7)$ & 0.652 \\
\hline First-pass TICI 2B-3 reperfusion (\%) & $157(44.4)$ & $137(43.6)$ & $20(51.3)$ & 0.364 \\
\hline Number of passes ${ }^{\dagger}$, median (IQR) & $3(2-4)$ & $3(2-4)$ & $2(2-3)$ & $0.036^{*}$ \\
\hline \multicolumn{5}{|l|}{ Symptomatic complication } \\
\hline Ischemic complication (\%) & $2(0.6)$ & $2(0.6)$ & $0(0)$ & 1.000 \\
\hline Hemorrhagic complication (\%) & $20(5.7)$ & $19(6.1)$ & $1(2.6)$ & 0.711 \\
\hline Puncture related complication (\%) & $8(2.3)$ & $7(2.2)$ & $1(2.6)$ & 1.000 \\
\hline Hospitalization period (IQR), day & $29(18-41)$ & $29.5(18.3-41)$ & $27(12-39)$ & 0.226 \\
\hline $\mathrm{mRS}$ at discharge & $3(2-5)$ & $3(2-5)$ & $4(2-5)$ & 0.325 \\
\hline $\mathrm{mRS} \leq 2$ at discharge $(\%)$ & $118(33.4)$ & $106(33.8)$ & $12(30.8)$ & 0.709 \\
\hline Mortality (\%) & $30(8.5)$ & $22(7.0)$ & $8(20.5)$ & $0.010^{*}$ \\
\hline
\end{tabular}

${ }^{*} p<0.05$. $\dagger$ In cases that were not achieved successful reperfusion in the first pass

$r t-P A$ recombinant tissue-type plasminogen activator, PTA percutaneous transluminal angioplasty, IQR interquartile range, TICI Thrombolysis in Cerebral Ischemia

significantly different, while successful reperfusion and favorable outcome demonstrated no significant differences between the groups. Previous reports have demonstrated that male preponderance [24], younger age [24, 37], higher NIHSS score [21, 22, 24], longer onset-to-puncture time [21, 37], longer onset-to-reperfusion time [37], higher rate of futile reperfusion [25], lower tendency of favorable outcome $[21-23,25]$, and higher mortality $[22,23,25]$ were observed in patients with posterior circulation occlusion. In contrast, there have also been some studies that reported similar or lower NIHSS scores [37, 38], lower rates of symptomatic hemorrhage [25, 37], similar rates of favorable outcome [37, $38]$, and similar mortality [24, 37, 38] between patients with anterior and those with posterior circulation occlusions. Our findings confirmed these characteristics using real-world clinical data from a single institution.

Posterior circulation is densely surrounded by areas responsible for sensory and motor functions as well as maintaining awake conditions; therefore, patients with posterior circulation occlusion tend to present in a severe state. Consequently, the NIHSS score in these patients could be higher than that in patients with anterior circulation occlusion. Additionally, the NIHSS score tended to be higher in patients with impaired consciousness, which may have affected the difference. In contrast, some studies have reported similar or lower NIHSS scores in posterior circulation occlusion in comparison with anterior circulation occlusion. These reports only included patients who underwent 
Fig. 1 Distribution of the modified Rankin Scale (mRS) scores at discharge in all patients and in those with anterior and posterior circulation occlusions

\section{Distribution of $\mathrm{mRS}$ at discharge}

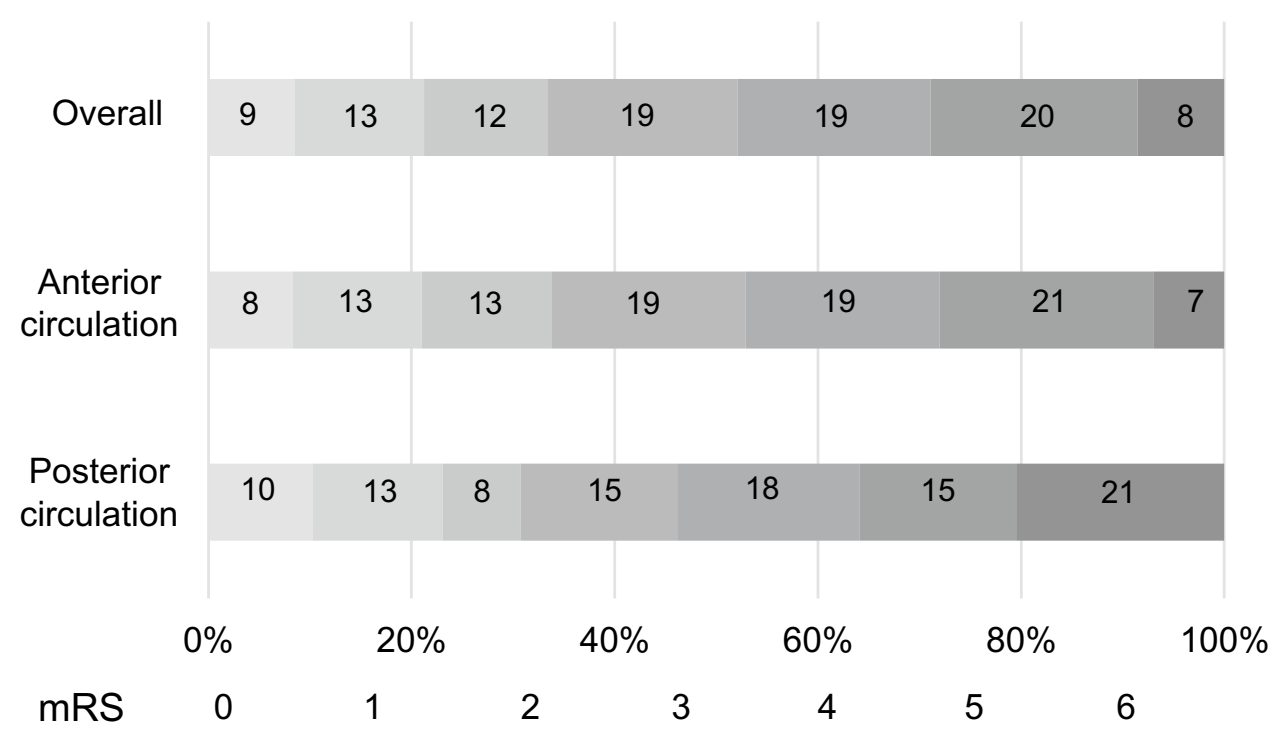

thrombectomy. However, because of the severity of presentation, patients with posterior circulation occlusion often miss the opportunity for acute recanalization therapy [39]; therefore, the NIHSS score might be underestimated. Additionally, the posterior circulation system is more resistant to ischemic insult with slower progression due to the greater amount of white matter and better collateral circulation than the anterior system [40, 41]. These features might have resulted in the lower NIHSS score in some patients. About disease subtype, in our study, patients with posterior circulation occlusion had more intracranial stenotic occlusions, although the successful reperfusion ratio did not significantly differ. In previous reports, higher rates of intracranial atherosclerosis-related occlusions were observed in patients

Table 3 Subgroup analysis according to the first-pass device

\begin{tabular}{|c|c|c|c|c|c|c|c|}
\hline \multirow[t]{2}{*}{ Characteristics } & \multirow[t]{2}{*}{ Location } & \multicolumn{3}{|l|}{ First-pass device } & \multicolumn{3}{|l|}{$p$ value } \\
\hline & & 1. Stent retriever & 2. Aspiration catheter & 3. Combined approach & 1 vs. 2 & 1 vs. 3 & 2 vs. 3 \\
\hline \multirow[t]{2}{*}{ Number of patients } & $\mathrm{AC}$ & 90 & 110 & 93 & & & \\
\hline & $\mathrm{PC}$ & 11 & 13 & 10 & & & \\
\hline \multirow{2}{*}{$\begin{array}{l}\text { Puncture-to-reperfusion time, median } \\
\text { (IQR), min }\end{array}$} & $\mathrm{AC}$ & $47(28.3-64.8)$ & $41.5(28-69)$ & $53.5(36.5-77)$ & 0.993 & 0.065 & $0.045^{*}$ \\
\hline & $\mathrm{PC}$ & $54(43-65)$ & $38.5(26-79.3)$ & $48(42-74)$ & 0.566 & 0.824 & 0.382 \\
\hline \multirow[t]{2}{*}{ TICI 2B-3 reperfusion (\%) } & $\mathrm{AC}$ & $75(83.3)$ & $91(82.7)$ & $77(82.8)$ & 0.910 & 0.923 & 0.990 \\
\hline & $\mathrm{PC}$ & $10(90.9)$ & $9(69.2)$ & $8(80.0)$ & 0.327 & 0.586 & 0.660 \\
\hline \multirow[t]{2}{*}{ TICI 3 reperfusion (\%) } & $\mathrm{AC}$ & $39(43.4)$ & $57(51.8)$ & $36(38.7)$ & 0.232 & 0.525 & 0.062 \\
\hline & $\mathrm{PC}$ & 7 (63.6) & $5(38.5)$ & $7(70.0)$ & 0.219 & 1.000 & 0.214 \\
\hline \multirow[t]{2}{*}{ First-pass TICI 2B-3 reperfusion (\%) } & $\mathrm{AC}$ & $41(45.6)$ & $48(43.6)$ & $44(47.3)$ & 0.786 & 0.812 & 0.600 \\
\hline & $\mathrm{PC}$ & $9(81.8)$ & $5(38.5)$ & $5(50.0)$ & $0.047^{*}$ & 0.183 & 0.685 \\
\hline \multirow[t]{2}{*}{ Symptomatic ischemic complications (\%) } & $\mathrm{AC}$ & $0(0)$ & $1(9.1)$ & $0(0)$ & 1.000 & NA & 1.000 \\
\hline & $\mathrm{PC}$ & $0(0)$ & $0(0)$ & $0(0)$ & NA & NA & NA \\
\hline \multirow{2}{*}{$\begin{array}{l}\text { Symptomatic hemorrhagic complications } \\
(\%)\end{array}$} & $\mathrm{AC}$ & $3(3.3)$ & $3(2.7)$ & $10(10.8)$ & 0.803 & 0.051 & $0.020 *$ \\
\hline & $\mathrm{PC}$ & $0(0)$ & $1(7.7)$ & $0(0)$ & 1.000 & NA & 1.000 \\
\hline \multirow[t]{2}{*}{$\mathrm{mRS} \leq 2$ at discharge $(\%)$} & $\mathrm{AC}$ & $30(33.3)$ & $43(39.1)$ & $26(28.0)$ & 0.400 & 0.430 & 0.095 \\
\hline & $\mathrm{PC}$ & $4(36.4)$ & $4(30.8)$ & $2(20.0)$ & 1.000 & 0.635 & 0.660 \\
\hline \multirow[t]{2}{*}{ Mortality (\%) } & $\mathrm{AC}$ & $4(4.4)$ & $8(7.3)$ & $7(7.5)$ & 0.402 & 0.380 & 0.945 \\
\hline & $\mathrm{PC}$ & $1(9.1)$ & $3(23.1)$ & $2(20.0)$ & 0.596 & 0.586 & 1.000 \\
\hline
\end{tabular}

${ }^{*} p<0.05 . I Q R$ interquartile range, $A C$ anterior circulation, $P C$ posterior circulation, $T I C I$ Thrombolysis in Cerebral Ischemia, $m R S$, modified Rankin Scale 
with posterior circulation occlusion than in those with anterior circulation occlusion, and successful reperfusion rates were not significantly different between atherosclerosisrelated and non-atherosclerosis-related occlusions [42]. Our study also confirmed these findings. Patients with posterior circulation occlusion need more time to be stabilized in the emergency room, such as the time required for endotracheal intubation, due to impaired consciousness. Additionally, a previous report has demonstrated that symptoms considered typical of posterior circulation infarction occur far less often than expected [43]. Various presentations were observed with posterior circulation occlusion in comparison with those with anterior circulation. We sometimes are not aware of the possibility of large vessel occlusion before imaging has been performed. These factors might lead to a delay in diagnosis as well as delay of treatment as observed in our results in posterior circulation occlusion. The number of passes in the cases that were not achieved successful reperfusion in the first pass, smaller diameter of vessels, and concerns of vascular damage might explain the fewer passes in the posterior circulation. From the perspective of outcome, a lower tendency of favorable outcome and higher mortality in posterior circulation occlusion might be due to the severity, such as higher NIHSS score. In prospective registry studies, despite the relatively high successful reperfusion rate, worse outcomes have been reported in posterior circulation occlusion [26, 27]. In contrast, despite the delayed treatment, some reports and our results demonstrate similar favorable outcomes and successful reperfusion ratio in posterior circulation occlusion as those in anterior circulation occlusion [24, 37, 38]. The aforementioned stronger resistance to ischemic insult might have affected these results. In our study, compared with patients with anterior circulation occlusion, a higher NIHSS score, more intracranial stenotic occlusions, delayed treatment, fewer passes, and higher mortality, as well as similar successful reperfusion rates and favorable outcomes, were observed in patients with posterior circulation occlusion. Similar favorable outcomes might be due to the similar successful reperfusion ratio, and improvements regarding delayed treatment and optimal firstpass strategy might result in better outcomes.

\section{Optimal treatment strategy}

Regarding the treatment strategy for posterior circulation occlusion, although there were only 39 patients, stent retrievers resulted in a higher rate of first-pass reperfusion with similar puncture-to-reperfusion time, rate of symptomatic complications, tendency of favorable outcome, and mortality as those with aspiration catheter and the combined approach in our subgroup analysis according to first-pass device. In a retrospective multicenter international study on posterior circulation occlusion, significantly shorter procedure time, higher TICI score, and higher tendency of favorable outcome were observed with the direct aspiration first-pass (ADAPT) technique in comparison with stent retrievers; however, there was no significant difference in comparison with the combined approach [21]. Additionally, Gory et al. reported that the ADAPT technique as the first-line strategy for posterior circulation occlusion resulted in a higher rate of TICI 3 reperfusion and shorter procedure [44]. These reports suggest that stent retriever could require more procedure time and lead to a lesser than favorable outcome. In contrast, Maus et al. reported that stent retrievers combined with aspiration catheters (stent retriever-assisted vacuum-locked extraction technique) resulted in a higher reperfusion rate than aspiration catheter only [45]. Therefore, aspiration or a combined approach might be recommended as a first-pass device for posterior circulation occlusion. However, in posterior circulation occlusion, the vessel diameter is sometimes small and the treatment options might be limited. A stent retriever can be used through a relatively small guiding catheter in these cases and may be considered the first choice based on our results.

\section{Limitations and future work}

This study had several limitations. The first treatment strategy depended on the neuroendovascular surgeons, periods, locations of lesions, and access routes, which might have affected the results. Second, the clinical outcome was based on the patient condition at discharge, and the median hospitalization period was only 29 days (range, 18-41). Most studies are based on the patient's condition at 90 days after the procedure; therefore, this difference might have affected our results. Finally, the retrospective study design and inadequate sample size might have weakened our findings. In the near future, it will be necessary to confirm our results in prospective studies with large sample sizes.

\section{Conclusions}

In this study, we compared the efficiency of thrombectomy for acute large vessel occlusion between the posterior and anterior circulation at a single institution. In comparison with patients with anterior circulation occlusion, those with posterior circulation had a significantly higher NIHSS score, more intracranial stenotic occlusions, delayed treatment, fewer passes, and higher mortality, while successful reperfusion and favorable outcomes were not significantly different between the two groups. Additionally, although the number of patients was small, the stent-first strategy resulted in a higher rate of first-pass reperfusion with similar puncture-to-reperfusion time, rate of symptomatic complications, tendency of favorable outcome, and mortality as 
other strategies and might be considered a first-pass device for posterior circulation occlusion depending on the vessel diameter. Similar favorable outcomes and reperfusion ratio to the anterior circulation might be achieved also in the posterior circulation; however, delayed treatment and the optimal first-pass strategy might need further improvement.

Acknowledgements I would like to thank all medical staff at the Saitama Medical University International Medical Center.

Source of Funding This work was supported in part by JSPS KAKENHI grant number 20K15933 (to T.K.).

\section{Compliance with ethical standards}

Conflict of interest We declare that we have no conflict of interest.

Ethical approval All procedures performed in the studies involving human participants were in accordance with the ethical standards of the institutional and/or national research committee and with the 1964 Helsinki Declaration and its later amendments or comparable ethical standards.

Informed consent This study protocol was approved by the ethics committee of Saitama Medical University International Medical Center (IRB number: 14-196), and all patients provided informed consent with an opt-out policy.

Open Access This article is licensed under a Creative Commons Attribution 4.0 International License, which permits use, sharing, adaptation, distribution and reproduction in any medium or format, as long as you give appropriate credit to the original author(s) and the source, provide a link to the Creative Commons licence, and indicate if changes were made. The images or other third party material in this article are included in the article's Creative Commons licence, unless indicated otherwise in a credit line to the material. If material is not included in the article's Creative Commons licence and your intended use is not permitted by statutory regulation or exceeds the permitted use, you will need to obtain permission directly from the copyright holder. To view a copy of this licence, visit http://creativecommons.org/licenses/by/4.0/.

\section{References}

1. Broderick JP, Palesch YY, Demchuk AM, Yeatts SD, Khatri P, Hill MD, Jauch EC, Jovin TG, Yan B, Silver FL, von Kummer R, Molina CA, Demaerschalk BM, Budzik R, Clark WM, Zaidat OO, Malisch TW, Goyal M, Schonewille WJ, Mazighi M, Engelter ST, Anderson C, Spilker J, Carrozzella J, Ryckborst KJ, Janis LS, Martin RH, Foster LD, Tomsick TA (2013) Endovascular therapy after intravenous t-PA versus t-PA alone for stroke. N Engl J Med 368(10):893-903

2. Ciccone A, Valvassori L, Nichelatti M, Sgoifo A, Ponzio M, Sterzi R, Boccardi E (2013) Endovascular treatment for acute ischemic stroke. N Engl J Med 368(10):904-913

3. Kidwell CS, Jahan R, Gornbein J, Alger JR, Nenov V, Ajani Z, Feng L, Meyer BC, Olson S, Schwamm LH, Yoo AJ, Marshall RS, Meyers PM, Yavagal DR, Wintermark M, Guzy J, Starkman S, Saver JL (2013) A trial of imaging selection and endovascular treatment for ischemic stroke. N Engl J Med 368(10):914-923
4. Berkhemer OA, Fransen PS, Beumer D, van den Berg LA, Lingsma HF, Yoo AJ, Schonewille WJ, Vos JA, Nederkoorn PJ, Wermer MJ, van Walderveen MA, Staals J, Hofmeijer J, van Oostayen JA, Lycklama à Nijeholt GJ, Boiten J, Brouwer PA, Emmer BJ, de Bruijn SF, van Dijk LC, Kappelle LJ, Lo RH, van Dijk EJ, de Vries J, de Kort PL, van Rooij WJ, van den Berg JS, van Hasselt BA, Aerden LA, Dallinga RJ, Visser MC, Bot JC, Vroomen PC, Eshghi O, Schreuder TH, Heijboer RJ, Keizer K, Tielbeek AV, den Hertog HM, Gerrits DG, van den Berg-Vos RM, Karas GB, Steyerberg EW, Flach HZ, Marquering HA, Sprengers ME, Jenniskens SF, Beenen LF, van den Berg R, Koudstaal PJ, van Zwam WH, Roos YB, van der Lugt A, van Oostenbrugge RJ, Majoie CB, Dippel DW (2015) A randomized trial of intraarterial treatment for acute ischemic stroke. N Engl J Med 372(1):11-20.

5. Campbell BC, Mitchell PJ, Kleinig TJ, Dewey HM, Churilov L, Yassi N, Yan B, Dowling RJ, Parsons MW, Oxley TJ, Wu TY, Brooks M, Simpson MA, Miteff F, Levi CR, Krause M, Harrington TJ, Faulder KC, Steinfort BS, Priglinger M, Ang T, Scroop R, Barber PA, McGuinness B, Wijeratne T, Phan TG, Chong W, Chandra RV, Bladin CF, Badve M, Rice H, de Villiers L, Ma H, Desmond PM, Donnan GA, Davis SM (2015) Endovascular therapy for ischemic stroke with perfusion-imaging selection. N Engl J Med 372(11):1009-1018

6. Goyal M, Demchuk AM, Menon BK, Eesa M, Rempel JL, Thornton J, Roy D, Jovin TG, Willinsky RA, Sapkota BL, Dowlatshahi D, Frei DF, Kamal NR, Montanera WJ, Poppe AY, Ryckborst KJ, Silver FL, Shuaib A, Tampieri D, Williams D, Bang OY, Baxter BW, Burns PA, Choe H, Heo JH, Holmstedt CA, Jankowitz B, Kelly M, Linares G, Mandzia JL, Shankar J, Sohn SI, Swartz RH, Barber PA, Coutts SB, Smith EE, Morrish WF, Weill A, Subramaniam S, Mitha AP, Wong JH, Lowerison MW, Sajobi TT, Hill MD (2015) Randomized assessment of rapid endovascular treatment of ischemic stroke. N Engl J Med 372(11):1019-1030

7. Jovin TG, Chamorro A, Cobo E, de Miquel MA, Molina CA, Rovira A, San Román L, Serena J, Abilleira S, Ribó M, Millán M, Urra X, Cardona P, López-Cancio E, Tomasello A, Castaño C, Blasco J, Aja L, Dorado L, Quesada H, Rubiera M, HernandezPérez M, Goyal M, Demchuk AM, von Kummer R, Gallofré M, Dávalos A (2015) Thrombectomy within 8 hours after symptom onset in ischemic stroke. N Engl J Med 372(24):2296-2306

8. Saver JL, Goyal M, Bonafe A, Diener HC, Levy EI, Pereira VM, Albers GW, Cognard C, Cohen DJ, Hacke W, Jansen O, Jovin TG, Mattle HP, Nogueira RG, Siddiqui AH, Yavagal DR, Baxter BW, Devlin TG, Lopes DK, Reddy VK, du Mesnil de Rochemont R, Singer OC, Jahan R (2015) Stent-retriever thrombectomy after intravenous t-PA vs. t-PA alone in stroke. N Engl J Med 372(24):2285-2295.

9. Goyal M, Menon BK, van Zwam WH, Dippel DW, Mitchell PJ, Demchuk AM, Dávalos A, Majoie CB, van der Lugt A, de Miquel MA, Donnan GA, Roos YB, Bonafe A, Jahan R, Diener HC, van den Berg LA, Levy EI, Berkhemer OA, Pereira VM, Rempel J, Millán M, Davis SM, Roy D, Thornton J, Román LS, Ribó M, Beumer D, Stouch B, Brown S, Campbell BC, van Oostenbrugge RJ, Saver JL, Hill MD, Jovin TG (2016) Endovascular thrombectomy after large-vessel ischaemic stroke: a meta-analysis of individual patient data from five randomised trials. Lancet 387(10029):1723-1731

10. Bracard S, Ducrocq X, Mas JL, Soudant M, Oppenheim C, Moulin T, Guillemin F (2016) Mechanical thrombectomy after intravenous alteplase versus alteplase alone after stroke (THRACE): a randomised controlled trial. Lancet Neurol 15(11):1138-1147

11. Muir KW, Ford GA, Messow CM, Ford I, Murray A, Clifton A, Brown MM, Madigan J, Lenthall R, Robertson F, Dixit A, Cloud GC, Wardlaw J, Freeman J, White P (2017) Endovascular therapy for acute ischaemic stroke: the Pragmatic Ischaemic Stroke 
Thrombectomy Evaluation (PISTE) randomised, controlled trial. J Neurol Neurosurg Psychiatry 88(1):38-44

12. Albers GW, Marks MP, Kemp S, Christensen S, Tsai JP, OrtegaGutierrez S, McTaggart RA, Torbey MT, Kim-Tenser M, LeslieMazwi T, Sarraj A, Kasner SE, Ansari SA, Yeatts SD, Hamilton S, Mlynash M, Heit JJ, Zaharchuk G, Kim S, Carrozzella J, Palesch YY, Demchuk AM, Bammer R, Lavori PW, Broderick JP, Lansberg MG (2018) Thrombectomy for stroke at 6 to 16 hours with selection by perfusion imaging. N Engl J Med 378(8):708-718

13. Nogueira RG, Jadhav AP, Haussen DC, Bonafe A, Budzik RF, Bhuva P, Yavagal DR, Ribo M, Cognard C, Hanel RA, Sila CA, Hassan AE, Millan M, Levy EI, Mitchell P, Chen M, English JD, Shah QA, Silver FL, Pereira VM, Mehta BP, Baxter BW, Abraham MG, Cardona P, Veznedaroglu E, Hellinger FR, Feng L, Kirmani JF, Lopes DK, Jankowitz BT, Frankel MR, Costalat V, Vora NA, Yoo AJ, Malik AM, Furlan AJ, Rubiera M, Aghaebrahim A, Olivot JM, Tekle WG, Shields R, Graves T, Lewis RJ, Smith WS, Liebeskind DS, Saver JL, Jovin TG (2018) Thrombectomy 6 to 24 hours after stroke with a mismatch between deficit and infarct. N Engl J Med 378(1):11-21

14. Lapergue B, Blanc R, Gory B, Labreuche J, Duhamel A, Marnat G, Saleme S, Costalat V, Bracard S, Desal H, Mazighi M, Consoli A, Piotin M (2017) Effect of endovascular contact aspiration vs stent retriever on revascularization in patients with acute ischemic stroke and large vessel occlusion: the ASTER randomized clinical trial. JAMA 318(5):443-452

15. Humphries W, Hoit D, Doss VT, Elijovich L, Frei D, Loy D, Dooley G, Turk AS, Chaudry I, Turner R, Mocco J, Morone P, Fiorella D, Siddiqui A, Mokin M, Arthur AS (2015) Distal aspiration with retrievable stent assisted thrombectomy for the treatment of acute ischemic stroke. J Neurointerv Surg 7(2):90-94

16. Massari F, Henninger N, Lozano JD, Patel A, Kuhn AL, Howk M, Perras M, Brooks C, Gounis MJ, Kan P, Wakhloo AK, Puri AS (2016) ARTS (Aspiration-Retriever Technique for Stroke): initial clinical experience. Interv Neuroradiol 22(3):325-332

17. McTaggart RA, Tung EL, Yaghi S, Cutting SM, Hemendinger M, Gale HI, Baird GL, Haas RA, Jayaraman MV (2017) Continuous aspiration prior to intracranial vascular embolectomy (CAPTIVE): a technique which improves outcomes. J Neurointerv Surg 9(12):1154-1159

18. Maus V, Behme D, Kabbasch C, Borggrefe J, Tsogkas I, Nikoubashman O, Wiesmann M, Knauth M, Mpotsaris A, Psychogios MN (2018) Maximizing first-pass complete reperfusion with SAVE. Clin Neuroradiol 28(3):327-338

19. Smith WS, Lev MH, English JD, Camargo EC, Chou M, Johnston SC, Gonzalez G, Schaefer PW, Dillon WP, Koroshetz WJ, Furie KL (2009) Significance of large vessel intracranial occlusion causing acute ischemic stroke and TIA. Stroke 40(12):3834-3840

20. Mattle HP, Arnold M, Lindsberg PJ, Schonewille WJ, Schroth G (2011) Basilar artery occlusion. Lancet Neurol 10(11):1002-1014

21. Alawieh AM, Eid M, Anadani M, Sattur M, Maier IL, Feng W, Goyal N, Starke RM, Rai A, Fargen KM, Psychogios MN, De Leacy R, Grossberg JA, Keyrouz SG, Dumont TM, Kan P, Lena J, Liman J, Arthur AS, Elijovich L, McCarthy DJ, Saini V, Wolfe SQ, Mocco J, Fifi JT, Nascimento FA, Giles JA, Allen M, Crosa R, Fox WC, Gory B, Spiotta AM (2020) Thrombectomy technique predicts outcome in posterior circulation stroke-insights from the STAR Collaboration. Neurosurgery 87(5):982-991

22. Huo X, Raynald GF, Ma N, Mo D, Sun X, Song L, Jia B, Pan Y, Wang Y, Liu L, Zhao X, Wang Y, Miao Z (2020) Characteristic and prognosis of acute large vessel occlusion in anterior and posterior circulation after endovascular treatment: the ANGEL registry real world experience. J Thromb Thrombolysis 49(4):527-532

23. Lee SH, Han JH, Jung I, Jung JM (2020) Do thrombolysis outcomes differ between anterior circulation stroke and posterior circulation stroke? A systematic review and meta-analysis. Int $\mathbf{J}$ Stroke 15(8):849-857

24. Uno J, Kameda K, Otsuji R, Ren N, Nagaoka S, Maeda K, Ikai Y, Gi H (2020) Mechanical thrombectomy for basilar artery occlusion compared with anterior circulation stroke. World Neurosurg 134:e469-e475

25. Wang F, Wang J, He Q, Wang L, Cao Y, Zhang H, Xu Z (2020) Mechanical thrombectomy for posterior circulation occlusion: a comparison of outcomes with the anterior circulation occlusion - a meta-analysis. J Atheroscler Thromb 27(12):1325-1339

26. Singer OC, Berkefeld J, Nolte CH, Bohner G, Haring HP, Trenkler J, Gröschel K, Müller-Forell W, Niederkorn K, Deutschmann H, Neumann-Haefelin T, Hohmann C, Bussmeyer M, Mpotsaris A, Stoll A, Bormann A, Brenck J, Schlamann MU, Jander S, Turowski B, Petzold GC, Urbach H, Liebeskind DS (2015) Mechanical recanalization in basilar artery occlusion: the ENDOSTROKE study. Ann Neurol 77(3):415-424

27. Schonewille WJ, Wijman CA, Michel P, Rueckert CM, Weimar C, Mattle HP, Engelter ST, Tanne D, Muir KW, Molina CA, Thijs V, Audebert H, Pfefferkorn T, Szabo K, Lindsberg PJ, de Freitas G, Kappelle LJ, Algra A (2009) Treatment and outcomes of acute basilar artery occlusion in the Basilar Artery International Cooperation Study (BASICS): a prospective registry study. Lancet Neurol 8(8):724-730

28. Liu X, Dai Q, Ye R, Zi W, Liu Y, Wang H, Zhu W, Ma M, Yin Q, Li M, Fan X, Sun W, Han Y, Lv Q, Liu R, Yang D, Shi Z, Zheng D, Deng X, Wan Y, Wang Z, Geng Y, Chen X, Zhou Z, Liao G, Jin P, Liu Y, Liu X, Zhang M, Zhou F, Shi H, Zhang Y, Guo F, Yin C, Niu G, Zhang M, Cai X, Zhu Q, Chen Z, Liang Y, Li B, Lin M, Wang W, Xu H, Fu X, Liu W, Tian X, Gong Z, Shi H, Wang C, Lv P, Tao Z, Zhu L, Yang S, Hu W, Jiang P, Liebeskind DS, Pereira VM, Leung T, Yan B, Davis S, Xu G, Nogueira RG (2020) Endovascular treatment versus standard medical treatment for vertebrobasilar artery occlusion (BEST): an open-label, randomised controlled trial. Lancet Neurol 19(2):115-122

29. Guillaume M, Lapergue B, Gory B, Labreuche J, Consoli A, Mione G, Humbertjean L, Lacour JC, Mazighi M, Piotin M, Blanc R, Richard S (2019) Rapid successful reperfusion of basilar artery occlusion strokes with pretreatment diffusion-weighted imaging posterior-circulation ASPECTS $<8$ is associated with good outcome. J Am Heart Assoc 8(10):e01096.

30. Alemseged F, Van der Hoeven E, Di Giuliano F, Shah D, Sallustio F, Arba F, Kleinig TJ, Bush S, Dowling RJ, Yan B, Sharma G, Limbucci N, Floris R, Donnan GA, Puetz V, Diomedi M, Parsons MW, Mitchell PJ, Davis SM, Yassi N, Schonewille WJ, Campbell BCV (2019) Response to late-window endovascular revascularization is associated with collateral status in basilar artery occlusion. Stroke https://doi.org/10.1161/strokeaha.118.023361:Strokeaha1 18023361 .

31. Li C, Zhao W, Wu C, Shang S, Chen J, Ren M, Duan J, Ma Q, Li G, Zhang Y, Zhang H, Jiao L, Ji X (2018) Outcome of endovascular treatment for acute basilar artery occlusion in the modern era: a single institution experience. Neuroradiology 60(6):651-659

32. Lyden P, Brott T, Tilley B, Welch KM, Mascha EJ, Levine S, Haley EC, Grotta J, Marler J (1994) Improved reliability of the NIH Stroke Scale using video training. NINDS TPA Stroke Study Group Stroke 25(11):2220-2226

33. Hirai T, Sasaki M, Maeda M, Ida M, Katsuragawa S, Sakoh M, Takano K, Arai S, Hirano T, Kai Y, Kakeda S, Murakami R, Ikeda R, Fukuoka H, Sasao A, Yamashita Y (2009) Diffusion-weighted imaging in ischemic stroke: effect of display method on observers' diagnostic performance. Acad Radiol 16(3):305-312

34. Puetz V, Khomenko A, Hill MD, Dzialowski I, Michel P, Weimar C, Wijman CA, Mattle HP, Engelter ST, Muir KW, Pfefferkorn T, Tanne D, Szabo K, Kappelle LJ, Algra A, von Kummer R, Demchuk AM, Schonewille WJ (2011) Extent of hypoattenuation 
on CT angiography source images in basilar artery occlusion: prognostic value in the Basilar Artery International Cooperation Study. Stroke 42(12):3454-3459

35. van Swieten JC, Koudstaal PJ, Visser MC, Schouten HJ, van Gijn J (1988) Interobserver agreement for the assessment of handicap in stroke patients. Stroke 19(5):604-607

36. Higashida RT, Furlan AJ, Roberts H, Tomsick T, Connors B, Barr J, Dillon W, Warach S, Broderick J, Tilley B, Sacks D (2003) Trial design and reporting standards for intra-arterial cerebral thrombolysis for acute ischemic stroke. Stroke 34(8):e109-137

37. Weber R, Minnerup J, Nordmeyer H, Eyding J, Krogias C, Hadisurya J, Berger K (2019) Thrombectomy in posterior circulation stroke: differences in procedures and outcome compared to anterior circulation stroke in the prospective multicentre REVASK registry. Eur J Neurol 26(2):299-305

38. Alawieh A, Vargas J, Turner RD, Turk AS, Chaudry MI, Lena J, Spiotta A (2018) Equivalent favorable outcomes possible after thrombectomy for posterior circulation large vessel occlusion compared with the anterior circulation: the MUSC experience. J Neurointerv Surg 10(8):735-740

39. Merwick Á, Werring D (2014) Posterior circulation ischaemic stroke. Bmj 348:g3175.

40. Vergouwen MD, Algra A, Pfefferkorn T, Weimar C, Rueckert CM, Thijs V, Kappelle LJ, Schonewille WJ (2012) Time is brain(stem) in basilar artery occlusion. Stroke 43(11):3003-3006

41. Ostrem JL, Saver JL, Alger JR, Starkman S, Leary MC, Duckwiler G, Jahan R, Vespa P, Villablanca JP, Gobin YP, Vinuela F,
Kidwell CS (2004) Acute basilar artery occlusion: diffusion-perfusion MRI characterization of tissue salvage in patients receiving intra-arterial stroke therapies. Stroke 35(2):e30-34

42. Tsang ACO, Orru E, Klostranec JM, Yang IH, Lau KK, Tsang FCP, Lui WM, Pereira VM, Krings T (2019) Thrombectomy outcomes of intracranial atherosclerosis-related occlusions. Stroke 50(6):1460-1466

43. Tao WD, Liu M, Fisher M, Wang DR, Li J, Furie KL, Hao ZL, Lin S, Zhang CF, Zeng QT, Wu B (2012) Posterior versus anterior circulation infarction: how different are the neurological deficits? Stroke 43(8):2060-2065

44. Gory B, Mazighi M, Blanc R, Labreuche J, Piotin M, Turjman F, Lapergue B (2018) Mechanical thrombectomy in basilar artery occlusion: influence of reperfusion on clinical outcome and impact of the first-line strategy (ADAPT vs stent retriever). J Neurosurg 129(6):1482-1491

45. Maus V, Styczen H, Liman J, Maier I, Brehm A, Tsogkas I, Psychogios MN (2019) Intracranial mechanical thrombectomy of large vessel occlusions in the posterior circulation using SAVE. BMC Neurol 19(1):197

Publisher's note Springer Nature remains neutral with regard to jurisdictional claims in published maps and institutional affiliations. 